\title{
Rainfall leaching is critical for long-term use of recycled water in the Salinas Valley
}

by Belinda E. Platts and Mark E. Grismer

In 1998, Monterey County Water Recycling Projects began delivering water to 12,000 acres in the northern Salinas Valley. Two years later, an ongoing study began assessing the effects of the recycled water on soil salinity. Eight sites are receiving recycled water and a control site is receiving only well water. In data collected from 2000 to 2012, soil salinity of the 36-inch-deep profile was on average approximately double that of the applied water, suggesting significant leaching from applied water (irrigation) or rainfall. In this study, we investigated some of the soil water hydrology factors possibly controlling the soil salinity results. Using soil water balance modeling, we found that rainfall had more effect on soil salinity than did leaching from irrigation. Increasing applied water usually only correlated significantly with soil salinity parameters in the shallow soil profile (1 to 12 inches depth) and at 24 to 36 inches at sites receiving fairly undiluted recycled water. Winter rains, though, had a critical effect. Increasing rainfall depths were significantly correlated with decreasing soil salinity of the shallow soil at all test sites, though this effect also diminished with increased soil depth. When applied water had high salinity levels, winter rainfall in this area was inadequate to prevent soil salinity from increasing.

\footnotetext{
Tsing recycled wastewater for agriculture and landscaping has environmental benefits because it limits the wastewater discharge into natural waterways while helping to preserve the supply of potable water for human consumption. Recycled water (tertiary-treated wastewater) has been used by a majority of growers in the Monterey County Water Recycling Projects (MCWRP)
}

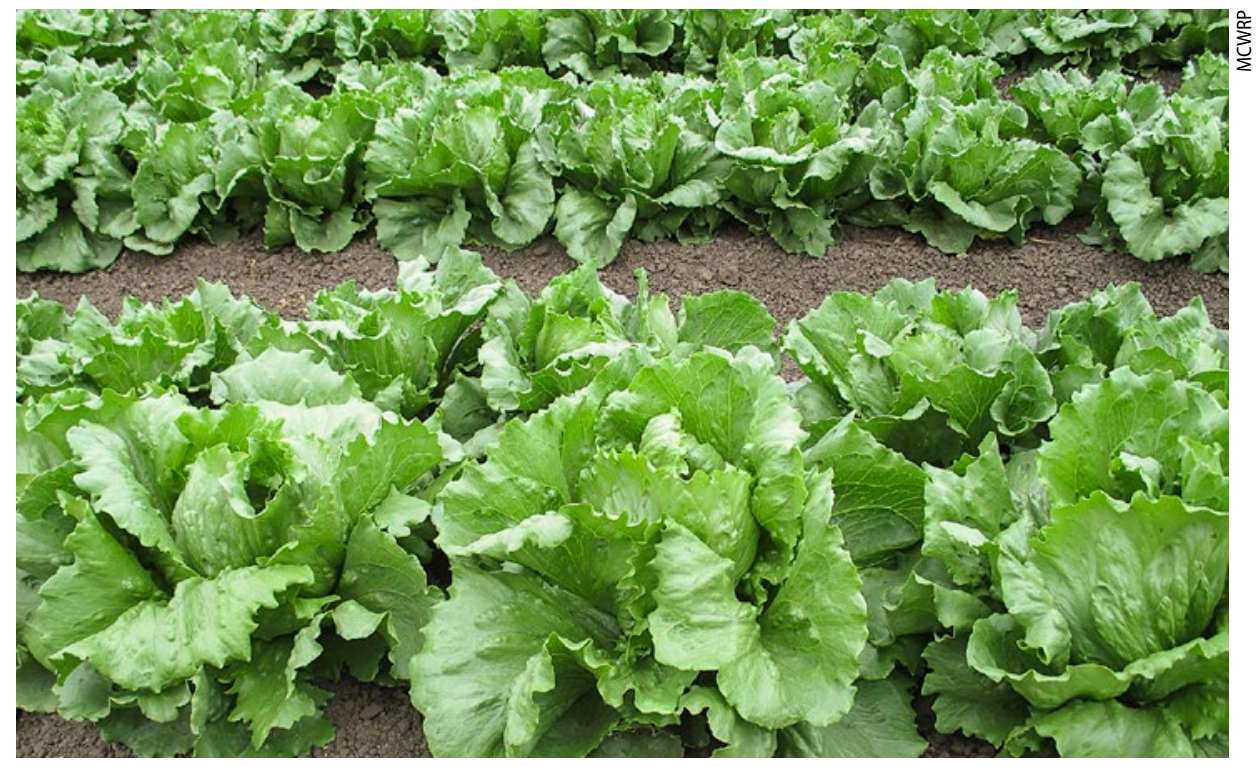

In a study of Salinas Valley fields irrigated with recycled wastewater, researchers found that rainfall leaching is an important factor in maintaining satisfactory root zone salinity levels for salt-sensitive crops such as lettuce and strawberries.

Salinas Valley area since 1998. An ongoing study, initiated in 2000, is comparing the changes in soil salinity between a field that has received only well water and eight field sites in the MCWRP area that have received recycled water since 1998. Each test site uses a specific blend of recycled water (the fraction ranges from $40 \%$ to $90 \%$ ) and well water for irrigation, allowing assessment of the relative impacts of the water quality on soil salinity parameters.

Recently, a feasibility study of the use of recycled water for vineyard irrigation in the Carneros and MillikenSarco-Tulocay (MST) regions near Napa indicated that leaching by winter rains averaging more than 20 inches a year was sufficient to maintain soil salinity, sodium $(\mathrm{Na})$ and chloride $(\mathrm{Cl})$ levels within acceptable ranges for grape production (Weber et al. 2014; page 59, this issue). Winter rainfall is about 13 inches a year in the MCWRP area, and our goal in this study was to ascertain the effectiveness of irrigation leaching compared with rainfall leaching.

Overall, the average soil salinity parameters - electrical conductivity $\left(\mathrm{EC}_{\mathrm{e}}\right)$, $\mathrm{Na}, \mathrm{Cl}$ and sodium adsorption ratio (SAR) - at the test sites were highly correlated with the average recycled water quality values, as we describe in our other article on this study (Platts and Grismer 2014; page 68, this issue). At the same time, with the exception of two sites ( 1 and 7$)$, average soil salinity parameter values remained roughly constant from one year to the next, suggesting the possibility of relatively steady-state leaching of the soil profile to a depth of 36 inches (i.e., on an annual basis the amount of salt added with irrigation is roughly equal to the amount leaving the bottom of the root zone).

Assuming that strawberry production is the most sensitive to soil $\mathrm{Cl}$ concentrations, the irrigation leaching requirement predicted from an annual salt balance consideration using the fairly undiluted recycled water $(\mathrm{Cl}$ at $7 \mathrm{meq} / \mathrm{L}$ [milliequivalents per liter]) for irrigation would be about $23 \%$ as compared to about $5 \%$ for well water with $\mathrm{Cl}$ at about $1.5 \mathrm{meq} / \mathrm{L}$. However, it was not clear from initial water quality analyses whether the differences in soil salinity parameters between the periods 2000-2009 and 2010-2012 were the result of irrigation alone, irrigation and rainfall, or rainfall alone.

Online: http://californiaagriculture.ucanr.edu/ landingpage.cfm?article =ca.v068n03p75\&fulltext=yes doi: 10.3733/ca.v068n03p75 
Distinguishing the soil water hydrologic factors controlling this apparent steady-state leaching situation (Grismer 1990) is critical for developing long-term sustainable recycled water use strategies in the region. To this end, we developed a root zone soil water balance model to determine the deep percolation from applied water (irrigation) and rainfall between soil sampling dates for comparison with changes in soil profile salinity parameters that occurred at the control and test sites.

\section{Root zone leaching processes}

For equivalent soil conditions, use of soil amendments and atmospheric dry deposition rates, the root zone salinity of irrigated soils largely depends on the applied water quality (salinity), frequency and duration of irrigation, evapotranspiration (ET) and rainfall depths, presuming adequate root zone drainage. Of course, irrigation usually occurs during the periods of the year with greater ET, resulting in a concentration of applied water salinity in the root zone through evaporation and transpiration processes. Irrigations at depths greater than that necessary to meet crop water demands generally occur either because of application inefficiency or for the purpose of leaching the root zone of accumulated salinity.

Generally, the salinity of rainwater is less than that of applied water, and in California deep percolation and leaching of root zone salinity occur during the winter rainy season, when ET rates are

\begin{tabular}{|c|c|c|c|c|}
\hline \multirow[b]{2}{*}{ Year } & \multicolumn{2}{|r|}{ Control site } & \multicolumn{2}{|r|}{ Site 6} \\
\hline & Crop & Plant date, harvest date & Crop & Plant date, harvest date \\
\hline \multirow[t]{2}{*}{2000} & Lettuce & $4 / 1,6 / 14$ & Lettuce & $4 / 20,6 / 28$ \\
\hline & Broccoli & $7 / 15,10 / 21$ & Broccoli & $7 / 20,10 / 20$ \\
\hline \multirow[t]{2}{*}{2001} & Lettuce & $5 / 13,7 / 20$ & Lettuce & $4 / 7,6 / 20$ \\
\hline & Lettuce & $8 / 15,10 / 20$ & Cauliflower & $7 / 6,10 / 19$ \\
\hline \multirow[t]{2}{*}{2002} & Lettuce & $5 / 23,7 / 28$ & Lettuce & $4 / 12,6 / 25$ \\
\hline & Lettuce & $8 / 22,10 / 31$ & Lettuce & $7 / 12,9 / 20$ \\
\hline \multirow[t]{2}{*}{2003} & Cabbage & $4 / 15,7 / 22$ & Broccoli & $4 / 10,7 / 7$ \\
\hline & Lettuce & $8 / 24,11 / 7$ & Celery & $7 / 21,10 / 25$ \\
\hline \multirow[t]{2}{*}{2004} & Lettuce & $5 / 1,7 / 10$ & Lettuce & $3 / 17,5 / 30$ \\
\hline & Broccoli & $8 / 20,12 / 5$ & Cauliflower & $6 / 15,9 / 20$ \\
\hline \multirow[t]{2}{*}{2005} & Lettuce & $4 / 3,6 / 15$ & Lettuce & $3 / 29,6 / 12$ \\
\hline & Cauliflower & $7 / 15,10 / 21$ & Lettuce & $6 / 29,9 / 4$ \\
\hline \multirow[t]{2}{*}{2006} & Lettuce & $5 / 10,7 / 18$ & Lettuce & $4 / 13,6 / 20$ \\
\hline & Lettuce & $8 / 10,10 / 27$ & Broccoli & $7 / 12,10 / 15$ \\
\hline \multirow[t]{2}{*}{2007} & Cauliflower & $11 / 20,4 / 7$ & Cauliflower & $1 / 30,5 / 15$ \\
\hline & Lettuce & $6 / 10,8 / 15$ & Lettuce & $6 / 2,8 / 7$ \\
\hline \multirow[t]{2}{*}{2008} & Lettuce & $3 / 15,6 / 8$ & \multirow[t]{2}{*}{ Strawberries } & \multirow[t]{2}{*}{$11 / 1 / 2007,10 / 24 / 2008$} \\
\hline & Lettuce & $7 / 4,9 / 15$ & & \\
\hline \multirow[t]{2}{*}{2009} & Lettuce & $4 / 7,6 / 22$ & Lettuce & $4 / 3,6 / 15$ \\
\hline & Broccoli & $7 / 22,10 / 28$ & Lettuce & $7 / 4,9 / 11$ \\
\hline \multirow[t]{2}{*}{2010} & Lettuce & $3 / 19,6 / 5$ & Lettuce & $1 / 2,4 / 20$ \\
\hline & Cauliflower & $6 / 26,9 / 28$ & Celery & $5 / 15,8 / 16$ \\
\hline \multirow[t]{2}{*}{2011} & Lettuce & $5 / 4,7 / 12$ & Cauliflower & $3 / 14,6 / 12$ \\
\hline & Lettuce & $8 / 5,10 / 18$ & Lettuce & $7 / 10,9 / 18$ \\
\hline \multirow[t]{2}{*}{2012} & Broccoli & $2 / 17,6 / 6$ & \multirow[t]{2}{*}{ Strawberries } & \multirow[t]{2}{*}{$11 / 20 / 2011,10 / 15 / 2012$} \\
\hline & Lettuce & $6 / 30,9 / 6$ & & \\
\hline
\end{tabular}

generally low. As a result, when there is sufficient rainwater displacement of concentrated applied water in the root zone, a greater decrease in root zone salinity per unit depth of rain is expected than that which would occur from the application of the same depth of more-saline applied water. Management of applied water and rainfall leaching of the soil root zone salinity is especially critical when growing salt-sensitive, high-value crops such as strawberries and leafy greens in the Salinas Valley.

\section{Soil water balance modeling}

With knowledge of the crop type, planting and harvest dates, soil type, typical applied water depths and local reference ET and rainfall, a daily root zone water balance can be developed to compute daily irrigation requirements as well as deep percolation (root zone drainage) depths. Water balances have been used to estimate deep percolation rates from desert alfalfa hay production (Bali et al. 2001; Grismer 2012) and from Sonoma County wine grape production (Grismer and Asato 2012) and also to corroborate field-measured soil profile drainage rates for avocado and citrus orchards on the central California coast (Grismer et al. 2000).

Grismer and Asato (2012) provide a detailed description of the general root zone water balance methods that were used here. However, we determined crop water use for the crops grown in the MCWRP region differently because water use changes daily as the crop grows. Water use by artichokes, strawberries, lettuce and cole (broccoli, cauliflower and rapini) crops depends on the relative canopy coverage of the crop, which in turn depends on the overall seasonal reference ET available to grow the crop. For our calculations, we used modified crop coefficient functions that depend on seasonal reference ET, and thus canopy coverage, originally developed by Gallardo et al. (1996), Grattan et al. (1998) and Hanson and Bendixen (2004) for the Salinas Valley region. From the crop season total reference ET and the canopy coverage functions, a daily increasing crop coefficient was determined and used to reduce reference ET to that of the crop ET. Daily rainfall and reference ET for the years 2000 to 2012 were taken as the average of the values from the three California 
Department of Water Resources CIMIS stations (Watsonville, Castroville and N. Salinas) in the study region.

As described in our companion paper (Platts and Grismer 2014; page 68), the salinity study involved a control site and eight test sites that had similar soil characteristics, drainage systems, types of crops grown (lettuce, cole crops and strawberries), irrigation method and farming practices. Table 1 presents cropping schedules from the control site and site 6, which are representative of the study sites. Generally, growers followed the management practices described in UC ANR Publications 7211 and 7216 (LeStrange et al. 2011; Smith et al. 2011), with three or four early-season sprinkler irrigations to establish the crops, followed by drip, furrow or additional sprinkler irrigations necessary to bring the crops to harvest.

In our root zone soil water balance modeling, an average 2.0 inches (5.1 centimeters) of water was applied when irrigation was needed to replenish root zone soil moisture levels necessary to meet crop water demands. Rainfall was assumed to be $60 \%$ effective as infiltration, and after the three or four initial planting irrigations, additional irrigations were triggered when soil moisture storage declined to less than half of capacity. A 2-inch water application depth is typical of the sprinkler systems used in the region, is greater than that from drip systems, and less than that from furrow irrigation systems. Our seasonal applied water depths ranged toward the low end of those reported for the region (Cahn et al. 2011; M. Cahn, UC Cooperative Extension Monterey County, personal communication) and, as is discussed below, most of the irrigation season deep percolation occurred as a result of the early-season irrigations used to establish the crop. Excess applied water or rainfall beyond that necessary to refill soil root zone water-holding capacity and meet daily crop ET was assumed to become deep percolation, or drainage, from the root zone.

\section{Water and soil sampling, analysis}

The recycled water (tertiary effluent from Monterey Regional Water Pollution Control Agency, MRWPCA) was sampled on a weekly basis to determine the levels of salt present in it before blending with the supplemental well water used to meet peak irrigation demand. Monthly delivery system sampling confirmed the quality of the water received by growers after supplemental well water was added to the recycled water. In addition, the quality of the well water delivered to the control site was sampled monthly. The water samples were analyzed for $\mathrm{pH}, \mathrm{EC}_{\mathrm{w}}, \mathrm{Na}, \mathrm{Mg}, \mathrm{Cl}$ and $\mathrm{K}$ (potassium) by an accredited laboratory run by MRWPCA.

The sites had Pacheco clay, clay-loam and sandy loam soils and subsurface tile drainage systems. At each site, soil

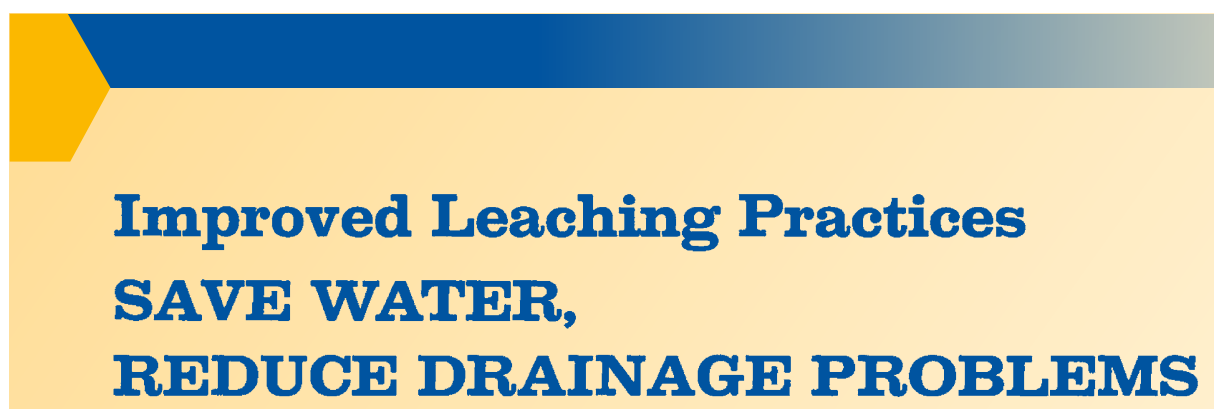

\begin{abstract}
This 1962 article from the California Agriculture archives demonstrated that intermittent water applications - in the form of rainfall or sprinkler irrigationleach unwanted or excess minerals from the topsoil much more effectively than the more-common ponded or flood applications.
\end{abstract}

\section{Early research on improved leaching practices}

1962 "Field studies conducted at Tule Lake provide striking evidence that ponding water is not always an efficient method of leaching. In some plots, as much as 6 acre-ft. of water per foot of soil depth was applied, yet the soil salinity was not reduced below one half of the original amount present. Of the six feet of water applied, the first one-half foot was responsible for the leaching obtained.

"During the winter months, 4 inches of rainfall was recorded. In this case the soil salinity was reduced by one half again, yet the quantity of water involved was 18 times less. Irrigation techniques can also be used to produce similar results. Reasons for these effects involve consideration of the structure of the soil and the variation in the pore velocity. Similar results have been found in other parts of the world. Reclamation of soils inundated by the sea in the Netherlands flood disaster of 1953 was more efficiently carried out by rainfall than by ponding."

Biggar JW, Nielsen DR. 1962. Improved leaching practices save water, reduce drainage problems. Calif Agr 16(3):5.

James W. Biggar was assistant irrigationist, Department of Irrigation, at UC Davis when this article was published in 1962. By the time of his retirement more than 30 years later, he was professor and water scientist in the UC Davis Department of Land, Air and Water Resources. Respected worldwide among agriculture professionals and environmental advocates for his research on soil properties, irrigation and the environmental fate of agricultural chemicals, Biggar was also highly regarded as a teacher and mentor by his students and eventual colleagues.

Co-author Donald R. Nielsen was, at the time of original publication, assistant professor in the UC Davis Department of Irrigation. Today he continues his work at UC Davis as emeritus professor in the Department of Land, Air and Water Resources.

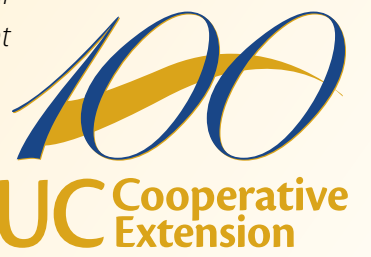


samples were collected from depths of 1 to 12 inches, 12 to 24 inches and 24 to 36 inches at four different locations within 3 feet of a designated global positioning system (GPS) point. Efforts were made to obtain comparable data year to year by collecting soil samples at three specific times in the production cycle: (1) following winter rains and prior to spring planting, (2) mid-growing season, after harvest of the first crop and (3) at the end of the growing season, after the second crop and before winter rains.

Soil samples at the four locations at each site were composited by soil depth. Sample analysis was done by an independent accredited lab (Valley Tech, Tulare, $\mathrm{CA}$ ) and included $\mathrm{pH}, \mathrm{EC}_{\mathrm{e}}$, extractable cations $\mathrm{B}$ (boron), $\mathrm{Ca}, \mathrm{Mg}, \mathrm{Na}$ and $\mathrm{K}$, and extractable anions $\mathrm{Cl}, \mathrm{NO}_{3}$ (nitrate) and $\mathrm{SO}_{4}$ (sulphate).

\section{Control and test site hydrology}

Despite the range in crops grown across the control and test sites, the average annual applied water depths ranged only from 22 to 26 inches, with an average of about 24 inches (60 centimeters) for all years, the same for the eight sites as a whole and the control site (table 2). Similarly, applied water deep percolation during the irrigation season ranged from about 15 to 18 inches, with the average amount at the test sites a little over an

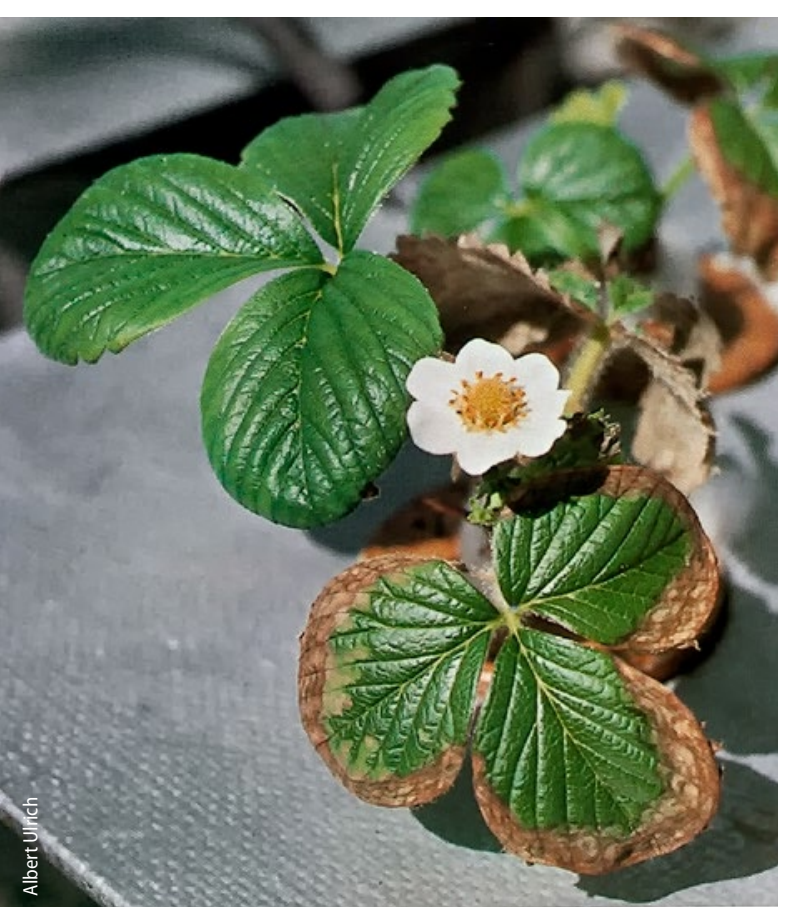

Toxic levels of salt cause strawberry leaf margins to turn brown and dry.

TABLE 2. Average annual hydrologic parameters associated with soil water balance calculations at the control site and eight test sites, 2000-2012

\begin{tabular}{|c|c|c|c|c|c|c|}
\hline \multirow[b]{2}{*}{ Location } & \multirow[b]{2}{*}{$\begin{array}{c}\text { Years } \\
\text { monitored }\end{array}$} & \multicolumn{3}{|c|}{ Irrigation season } & \multicolumn{2}{|c|}{ Non-irrigation season } \\
\hline & & Rain & $\mathrm{AW}^{*}$ & AW DP† & Rain & $\begin{array}{c}\text { Pre-spring } \\
\text { planting rain } \\
\text { DP }\end{array}$ \\
\hline & no. & & …... & - inches.. & n... & $\cdots \cdots \cdots$ \\
\hline Control & 13 & 2.91 & 24.31 & 15.76 & 11.60 & 4.55 \\
\hline Site 1 & $10 \neq$ & 2.89 & 24.80 & 14.79 & 11.62 & 5.35 \\
\hline Site 2 & 13 & 2.83 & 24.00 & 16.77 & 11.68 & 5.42 \\
\hline Site 3 & $10 \neq$ & 3.45 & 25.80 & 18.18 & 11.06 & 4.18 \\
\hline Site 4 & 13 & 3.01 & 22.15 & 16.75 & 11.50 & 4.99 \\
\hline Site 5 & 13 & 3.01 & 22.15 & 16.75 & 11.50 & 4.99 \\
\hline Site 6 & 13 & 4.49 & 25.38 & 18.13 & 10.02 & 4.82 \\
\hline Site 7 & 13 & 2.06 & 25.85 & 18.31 & 13.30 & 5.51 \\
\hline Site 8 & $7 \S$ & 1.21 & 23.14 & 16.92 & 13.30 & 6.39 \\
\hline \multicolumn{2}{|c|}{ Average of sites $1-8$} & 2.87 & 24.16 & 17.08 & 11.75 & 5.44 \\
\hline
\end{tabular}

${ }^{*} \mathrm{AW}=$ applied water.

† DP = deep percolation.

₹ Monitored from 2000 to 2009 only.

$\S$ Monitored from 2003 to 2009 only.

inch greater than that at the control site. Average rain depths during the irrigation season were more variable, ranging from just over 1 inch to about 4.5 inches, though the average of the test sites was essentially equivalent to that of the control site. Deep percolation leaching from rain between irrigation seasons (i.e., before spring planting) was practically the same at the control site as the average amount at the test sites, about 5.4 inches. The data in table 2 underscores the relative hydrologic similarity of the test sites and the control site, suggesting that reasonable leaching comparisons can be made.

Figures 1 and 2 show the accumulated daily rainfall, applied water and deep percolation at the control site and site 6 during an average ET and rainfall year, 2009. They illustrate the soil water balance modeling processes important for the leaching of soil salinity: At both sites, rainfall recharge incurs soil water deep percolation leaching during the first 2 months of the year and to a lesser extent the last month of the year, whereas applied water recharge, primarily from early-season planting irrigations, is responsible for most of the annual deep percolation leaching during the remainder of the year.

\section{Control and test site salinity}

Using daily soil water balance modeling, it was possible at each site to more precisely determine the deep percolation (leaching) from rain, irrigation or a combination of irrigation and rain that occurred between the soil sampling days in early spring, midsummer and late fall. The changes in soil salinity parameters are described in detail in our other article (Platts and Grismer 2014; page 68, in this issue). As noted there, three of the four primary salinity parameters, $\mathrm{Na}, \mathrm{Cl}$ and SAR, followed a similar pattern in changes from year to year that contrasted in part with that for EC. As the pairs of parameters - $\mathrm{Cl}$ and $\mathrm{EC}, \mathrm{Na}$ and SAR - are closely related, for brevity here we focus on changes in EC and Na concentrations at each soil depth and the hydrological processes associated with them.

In 2000 , soil EC $\left(\mathrm{EC}_{\mathrm{e}}\right)$ and Na concentrations generally increased with increasing depth at all the sites (table 3). The values at sites 2, 3, 4 and 6 were roughly equivalent to those at the control site; at sites 1, 5, 7 and 8, values were much greater. Approximately a decade later, $\mathrm{EC}_{\mathrm{e}}$ and $\mathrm{Na}$ concentrations had increased slightly in the 1 to 12 inches subprofile at the control site and sites 2, 3 and 4, while decreasing at site 6 . Changes in the whole profile averages (the sum of the amounts at the three subprofiles) of $\mathrm{EC}_{\mathrm{e}}$ and $\mathrm{Na}$ were mixed at the control site (i.e., there was a slight increase in $\mathrm{EC}_{\mathrm{e}}$ and a decrease in $\mathrm{Na}$ ) and site 4 (i.e., an increase in $\mathrm{Na}$ and a slight decrease in $\mathrm{EC}_{\mathrm{e}}$ ); at sites 2 and $6, \mathrm{EC}_{\mathrm{e}}$ and $\mathrm{Na}$ decreased; and at site 5 , they increased slightly. At sites 3 and 7 , 


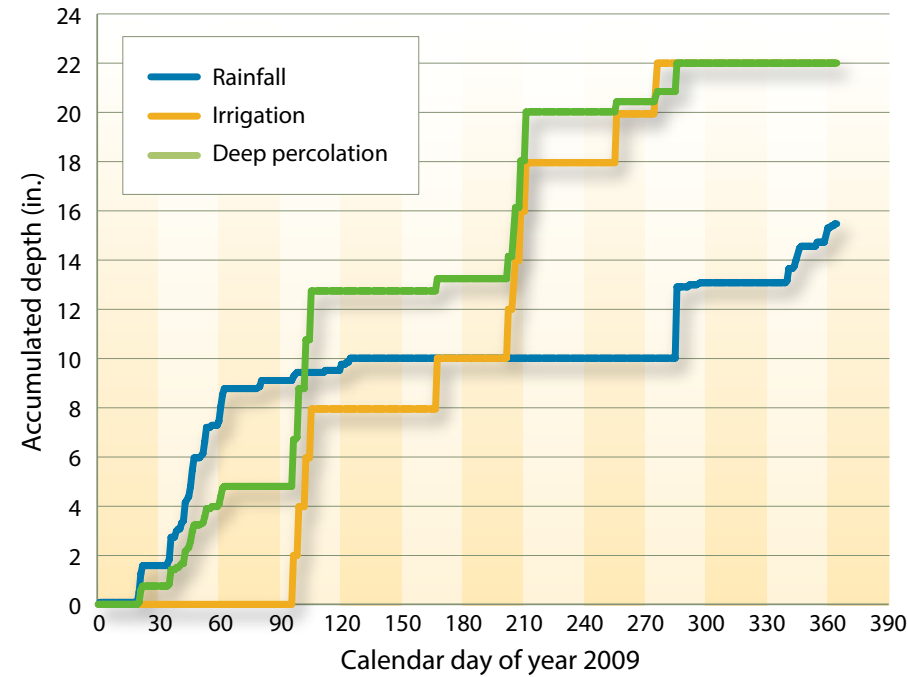

Fig. 1. Accumulated rainfall, irrigation and deep percolation depths at control site, 2009.

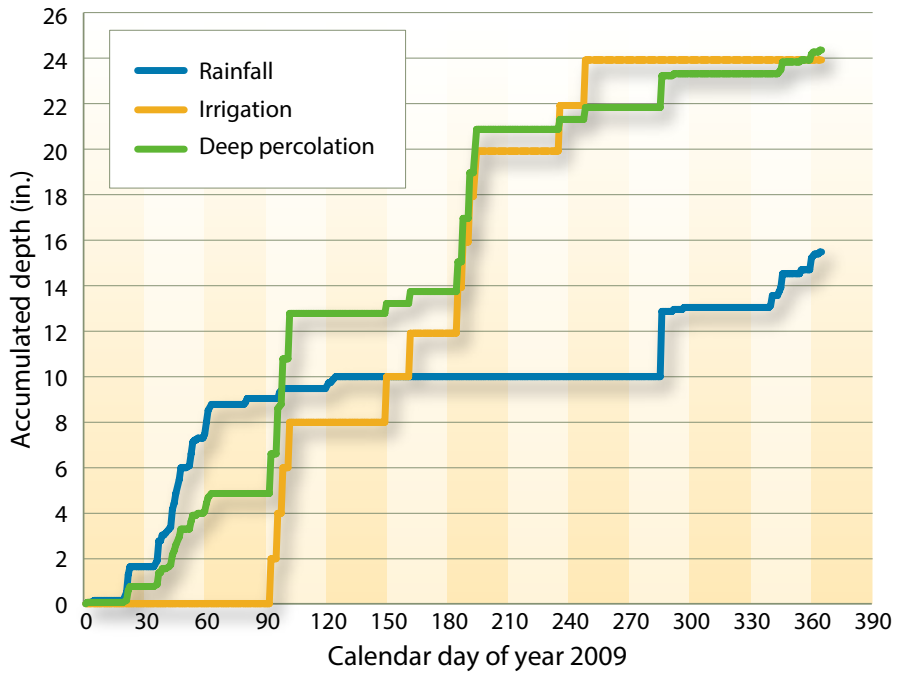

Fig. 2. Accumulated rainfall, irrigation and deep percolation depths at site 6, 2009.

TABLE 3. Hydrologic parameters associated with soil water balance modeling and changes in EC and Na levels after 7 to 13 years of monitoring

\begin{tabular}{|c|c|c|c|c|c|c|c|c|c|c|c|}
\hline \multirow{2}{*}{$\begin{array}{l}\text { Site } \\
\text { (no. years } \\
\text { monitored) }\end{array}$} & \multicolumn{5}{|c|}{$\mathrm{AW}^{*}$} & \multirow[b]{2}{*}{ Rain DP } & \multirow[b]{2}{*}{ Soil depth } & \multirow{2}{*}{$\begin{array}{c}\begin{array}{c}\text { Spring } \\
2000\end{array} \\
\mathrm{EC}_{\mathrm{e}}\end{array}$} & \multirow{2}{*}{$\begin{array}{c}\text { Spring } 2009 \\
\text { or } 2012 \\
\begin{array}{c}\text { Change in } \\
\mathrm{EC}_{\mathrm{e}}\end{array} \\
\end{array}$} & \multirow{2}{*}{$\begin{array}{c}\begin{array}{c}\text { Spring } \\
2000\end{array} \\
\mathrm{Na}_{\mathrm{e}} \\
\end{array}$} & \multirow{2}{*}{$\begin{array}{c}\begin{array}{c}\text { Spring } 2009 \\
\text { or } 2012\end{array} \\
\begin{array}{c}\text { Change in } \\
\mathrm{Na}_{\mathrm{e}}\end{array}\end{array}$} \\
\hline & \multirow{2}{*}{$\begin{array}{c}\text { Total AW } \\
\text { inches }\end{array}$} & \multirow{2}{*}{$\begin{array}{c}\begin{array}{c}\text { Recycled } \\
\text { water fraction }\end{array} \\
\% \\
\end{array}$} & \multirow{2}{*}{$\frac{E C_{w}}{d S / m}$} & \multirow{2}{*}{$\frac{\mathrm{Na}_{\mathrm{w}}}{\mathrm{meq} / \mathrm{L}}$} & AW DPt & & & & & & \\
\hline & & & & & n.w. & .. inches.. & n.w. & $\ldots \ldots$ & $5 / m \ldots \ldots$ & $\ldots \ldots \ldots$ & $q / L \ldots \ldots \ldots$ \\
\hline \multirow[t]{3}{*}{ Control (13) } & \multirow[t]{3}{*}{316} & \multirow[t]{3}{*}{0} & \multirow[t]{3}{*}{0.78} & \multirow[t]{3}{*}{3.52} & \multirow[t]{3}{*}{204.8} & \multirow[t]{3}{*}{54.6} & 12 & 0.82 & 0.62 & 3.4 & 1.8 \\
\hline & & & & & & & 24 & 0.87 & 0.14 & 4.4 & -0.5 \\
\hline & & & & & & & 36 & 1.00 & -0.01 & 6.0 & -1.9 \\
\hline \multirow[t]{3}{*}{ Site $1(10)$} & \multirow[t]{3}{*}{248} & \multirow[t]{3}{*}{69} & \multirow[t]{3}{*}{1.13} & \multirow[t]{3}{*}{5.85} & \multirow[t]{3}{*}{147.9} & \multirow[t]{3}{*}{42.8} & 12 & 1.87 & -0.33 & 6.8 & -0.2 \\
\hline & & & & & & & 24 & 2.63 & 0.18 & 10.2 & 0.9 \\
\hline & & & & & & & 36 & 3.28 & 0.72 & 12.9 & 0.5 \\
\hline \multirow[t]{3}{*}{ Site 2 (13) } & 312 & 46 & 1.12 & 5.81 & 218.1 & 65.0 & 12 & 0.80 & 0.36 & 3.7 & 1.2 \\
\hline & & & & & & & 24 & 1.52 & -0.34 & 5.7 & -0.8 \\
\hline & & & & & & & 36 & 2.53 & -1.03 & 6.4 & -0.6 \\
\hline Site $3(10)$ & 258 & 94 & 1.19 & 6.19 & 181.8 & 37.7 & 12 & 0.93 & 0.15 & 2.3 & 3.7 \\
\hline & & & & & & & 24 & 0.77 & 1.98 & 3.5 & 8.7 \\
\hline & & & & & & & 36 & 0.89 & 1.36 & 3.1 & 9.4 \\
\hline Site 4 (13) & 288 & 58 & 1.17 & 6.06 & 217.8 & 59.8 & 12 & 1.19 & 0.22 & 5.1 & 2.2 \\
\hline & & & & & & & 24 & 2.08 & -0.37 & 5.6 & 2.7 \\
\hline & & & & & & & 36 & 1.79 & -0.20 & 4.7 & 3.3 \\
\hline Site 5 (13) & 288 & 93 & 1.21 & 6.38 & 217.8 & 59.8 & 12 & 1.06 & 0.04 & 7.0 & -0.9 \\
\hline & & & & & & & 24 & 1.70 & 0.51 & 11.8 & 0.4 \\
\hline & & & & & & & 36 & 2.27 & 0.89 & 18.2 & 3.0 \\
\hline Site 6 (13) & 330 & 70 & 1.09 & 5.71 & 235.7 & 48.2 & 12 & 1.28 & -0.32 & 5.9 & -3.4 \\
\hline & & & & & & & 24 & 2.07 & -0.30 & 7.7 & 2.4 \\
\hline & & & & & & & 36 & 1.97 & -0.69 & 7.2 & -7.2 \\
\hline Site 7 (13) & 336 & 96 & 1.17 & 6.03 & 238.0 & 66.2 & 12 & 3.33 & 2.20 & 14.0 & 8.8 \\
\hline & & & & & & & 24 & 3.97 & 0.24 & 17.3 & 4.1 \\
\hline & & & & & & & 36 & 5.21 & -1.54 & 28.3 & -3.7 \\
\hline Site $8(7)$ & 162 & 87 & 1.41 & 7.32 & 118.5 & 44.7 & 12 & 1.37 & -0.34 & 9.2 & -3.3 \\
\hline & & & & & & & 24 & 3.33 & -0.61 & 22.8 & -8.1 \\
\hline & & & & & & & 36 & 2.57 & -0.29 & 17.7 & -2.8 \\
\hline
\end{tabular}

* AW = applied water.

$+\mathrm{DP}=$ deep percolation. 
there were relatively larger increases in $\mathrm{EC}_{\mathrm{e}}$ and $\mathrm{Na}$ concentrations in the whole profile after 13 years; and at site 8 , substantial decreases occurred in these values after 7 years. Generally, whole profile averages of both $\mathrm{EC}_{\mathrm{e}}$ and $\mathrm{Na}$ increased.

Considering the long-term changes in salinity parameters occurring between spring soil sampling in 2000 and spring soil sampling in 2009 or 2012, we found that none of the changes in $\mathrm{EC}_{\mathrm{e}}$ and $\mathrm{Na}$ concentrations at the subprofile or whole profile levels were correlated with the amount of applied water, or the applied water and rain deep percolation depths. This suggested that we needed to do a more detailed (shorter time period) analysis to distinguish differences in leaching effectiveness associated with rain or excess irrigation; the results of that analysis are described below.

\section{Leaching of soil salinity}

Using the soil water balance calculations to determine the deep percolation (leaching) from applied water or rainfall

\begin{tabular}{|c|c|c|c|c|c|c|}
\hline \multicolumn{7}{|c|}{$\begin{array}{c}\text { TABLE 4. Significant ( }>90 \% \text { confidence level) correlation statistics between changes in soil salinity } \\
\text { parameters and associated applied water deep percolation from all data after } 7 \text { to } 13 \text { years of } \\
\text { monitoring }\end{array}$} \\
\hline Site & $\begin{array}{c}\text { Salinity } \\
\text { parameter }\end{array}$ & Soil depth & Sample pairs & $\begin{array}{l}\text { Correlation } \\
\text { coefficient } r\end{array}$ & $\begin{array}{c}\text { Confidence } \\
\text { level }\end{array}$ & Linear regression slope \\
\hline & & inches & no. & & $\%$ & $d S / m /$ inch or $m e q / L /$ inch \\
\hline Control & EC & $12-24$ & 31 & -0.316 & 91.9 & -0.06 \\
\hline Site 1 & $\mathrm{Na}$ & $0-12$ & 34 & -0.335 & 94.8 & -0.36 \\
\hline Site 3 & $\mathrm{Na}$ & $0-12$ & 27 & 0.396 & 96.0 & 0.48 \\
\hline Site 5 & $\mathrm{Na}$ & $24-36$ & 35 & 0.362 & 96.8 & 0.46 \\
\hline \multirow[t]{4}{*}{ Site 8} & EC & $0-12$ & 14 & 0.667 & 99.2 & 0.18 \\
\hline & EC & $24-36$ & 14 & 0.504 & 93.7 & 0.05 \\
\hline & $\mathrm{Na}$ & $0-12$ & 14 & 0.681 & 99.4 & 0.67 \\
\hline & $\mathrm{Na}$ & $24-36$ & 14 & 0.479 & 92.0 & 0.35 \\
\hline
\end{tabular}

\begin{tabular}{|c|c|c|c|c|c|c|}
\hline Site & $\begin{array}{c}\text { Salinity } \\
\text { parameter }\end{array}$ & Soil depth & Sample pairs & $\begin{array}{l}\text { Correlation } \\
\text { coefficient } r\end{array}$ & $\begin{array}{c}\text { Confidence } \\
\text { level }\end{array}$ & Linear regression slope \\
\hline & & inches & no. & & $\%$ & $d S / m /$ inch or meq/L/inch \\
\hline \multirow[t]{2}{*}{ Control } & EC & $24-36$ & 17 & 0.468 & 94.4 & 0.30 \\
\hline & $\mathrm{Na}$ & $24-36$ & 17 & 0.444 & 92.8 & 0.09 \\
\hline \multirow[t]{2}{*}{ Site 1} & EC & $24-36$ & 17 & 0.460 & 93.9 & 0.31 \\
\hline & $\mathrm{Na}$ & $24-36$ & 17 & 0.413 & 90.3 & 0.92 \\
\hline \multirow[t]{2}{*}{ Site 3} & EC & $0-12$ & 15 & -0.435 & 91.0 & -0.34 \\
\hline & $\mathrm{Na}$ & $0-12$ & 15 & -0.480 & 93.3 & -0.90 \\
\hline \multirow[t]{4}{*}{ Site 5} & EC & $0-12$ & 23 & -0.661 & 99.9 & -0.45 \\
\hline & $\mathrm{Na}$ & $0-12$ & 23 & -0.663 & 99.8 & -0.24 \\
\hline & EC & $12-24$ & 23 & -0.611 & 99.9 & -1.78 \\
\hline & $\mathrm{Na}$ & $12-24$ & 23 & -0.473 & 97.8 & -0.78 \\
\hline \multirow[t]{4}{*}{ Site 6} & EC & $0-12$ & 23 & -0.518 & 98.9 & -0.25 \\
\hline & $\mathrm{Na}$ & $0-12$ & 23 & -0.528 & 96.7 & -0.81 \\
\hline & EC & $24-36$ & 23 & 0.444 & 99.1 & 0.07 \\
\hline & $\mathrm{Na}$ & $24-36$ & 23 & 0.399 & 94.2 & 0.20 \\
\hline \multirow[t]{2}{*}{ Site 7} & EC & $0-12$ & 20 & -0.429 & 94.2 & -0.19 \\
\hline & $\mathrm{Na}$ & 0-12 & 20 & -0.405 & 92.5 & -0.69 \\
\hline Site 8 & $\mathrm{Na}$ & $0-12$ & 9 & -0.749 & 98.5 & -1.49 \\
\hline
\end{tabular}


TABLE 6. Significant (>90\% confidence level) correlation statistics between changes in soil salinity parameters and associated deep percolation from applied water only or rain only after 7 to 13 years of monitoring

\begin{tabular}{|c|c|c|c|c|c|c|c|}
\hline Site & Type of DP* & $\begin{array}{c}\text { Salinity } \\
\text { parameter }\end{array}$ & Soil depth & Sample pairs & $\begin{array}{l}\text { Correlation } \\
\text { coefficient } r\end{array}$ & Confidence level & Linear regression slope \\
\hline & & & inches & no. & & $\%$ & $d S / m /$ inch or meq/L/inch \\
\hline Control & AWt & EC & $12-24$ & 26 & -0.335 & 90.7 & -0.05 \\
\hline Site 1 & AW & $\mathrm{Na}$ & $0-12$ & 14 & -0.461 & 90.6 & -0.47 \\
\hline Site 3 & AW & $\mathrm{Na}$ & $0-12$ & 16 & 0.463 & 93.2 & 0.38 \\
\hline \multirow[t]{3}{*}{ Site 5} & AW & EC & $0-12$ & 17 & 0.427 & 90.4 & 0.17 \\
\hline & AW & EC & $24-36$ & 17 & 0.679 & 99.7 & 0.15 \\
\hline & AW & $\mathrm{Na}$ & $24-36$ & 17 & 0.613 & 99.0 & 1.00 \\
\hline \multirow[t]{2}{*}{ Site 7} & AW & EC & $24-36$ & 17 & 0.569 & 98.4 & 0.20 \\
\hline & AW & $\mathrm{Na}$ & $24-36$ & 17 & 0.541 & 97.7 & 0.98 \\
\hline \multirow[t]{3}{*}{ Site 8} & AW & EC & $0-12$ & 10 & 0.688 & 97.7 & 0.16 \\
\hline & AW & EC & $24-36$ & 10 & 0.584 & 93.1 & 0.04 \\
\hline & AW & $\mathrm{Na}$ & $0-12$ & 10 & 0.785 & 99.5 & 0.55 \\
\hline \multirow{2}{*}{$\begin{array}{l}\text { Average of all } \\
\text { sites }\end{array}$} & Rain & EC & $0-12$ & 29 & -0.466 & 99.0 & -0.33 \\
\hline & Rain & $\mathrm{Na}$ & $0-12$ & 29 & -0.489 & 99.3 & -1.21 \\
\hline
\end{tabular}

* DP = deep percolation

† AW = applied water.

\section{Overall, rainfall leaching of the soil profile is critical for the sustained irrigation of the salt-sensitive crops in this area with recycled water.}

table 5). Crop yields from all of the sites appeared to be acceptable with an applied water $\mathrm{EC}_{\mathrm{w}}$ of 1.1 to 1.2 and $\mathrm{Na}$ as high as $6 \mathrm{meq} / \mathrm{L}$, values which are greater than those generally assumed to be suitable. Overall, the correlation analyses underscore the importance of rain-driven soil water leaching for maintaining satisfactory root zone salinity conditions.

\section{Rainfall leaching critical}

Comparison of the overall changes in soil salinity parameters from the beginning of soil sampling in spring 2000 to that in 2012 (or 2009 at two sites) yielded mixed results with little clear conclusion possible. However, when we considered the changes occurring between sampling events ( 1 to 5 months), the effects of rain and irrigation leaching became more apparent. At the control and the test sites, rainfall leaching of salinity was critical for maintaining agronomically acceptable soil salinity parameters in the root zone.

Irrigation leaching of the soil profile at the control site reduced salinity in the near-surface soil depth (1 to 12 inches) but may be resulting in a slight increase in $\mathrm{Na}$ concentrations at deeper depths (24 to 36 inches). At the test sites using irrigation water with greater salinity (high amounts of recycled water), despite considerable leaching fractions, irrigation leaching resulted in greater salinity concentrations in the near-surface soils and possible accumulation at deeper levels. Overall, rainfall leaching of the soil profile is critical for the sustained irrigation of the saltsensitive crops in this area with recycled water of the quality documented in this study, and this should be considered in the water use management strategies of the region.

B.E. Platts is Agricultural Consultant, Monterey Regional Water Pollution Control Agency (MRWPCA); and M.E. Grismer is Professor of Hydrologic Science and Biological and Agricultural Engineering, Department of Land, Air and Water Resources, UC Davis.

MCWRA has voluntarily funded the water and soil sampling monitoring program and collection of cropping data. We acknowledge the support of MRWPCA personnel and growers within the MCWRP area as being critical to the success of this study.

California Agriculture thanks Guest Associate Editor Stephen R. Grattan for his work on this article.

\section{References}

Bali KM, Grismer ME, Snyder RL. 2001. Alfalfa water use pinpointed in saline, shallow water tables of Imperial Valley. Calif Agr 55(4):38-43.

Cahn M, Farrara B, Bottoms TG, et al. 2011. Irrigation management and water use of California strawberries. ASHS Annual Conference Abstracts Hort. Science 46(9):S116. Sept. 25-28.

Gallardo M, Snyder RL, Schulbach K, Jackson LE. 1996. Crop growth and water use model for lettuce. J Irrig Drain E-ASCE 122(6):354-9.

Grattan SR, Bowers W, Dong A, et al. 1998. New crop coefficients estimate water use of vegetables, row crops. Calif Agr 52(1):16-21.

Grismer ME. 1990. Leaching fraction, soil salinity, and drainage efficiency. Calif Agr 44(6):24-7.

Grismer ME. 2012. Estimating agricultural deep percolation lag times to groundwater in the Antelope Valley, CA. Hydrol Process 27(3):378-93. doi:10.1002/ hyp.9249.

Grismer ME, Asato C. 2012. Converting oak woodland or savanna to vineyards may stress groundwater supply in summer. Calif Agr 66(4):144-52.

Grismer ME, Bachman S, Powers T. 2000. Comparison of groundwater recharge estimation methods in a semi-arid, coastal avocado/citrus orchard, Ventura County, CA. Hydrol Process 14(14):2527-43.

Hanson BR, Bendixen W. 2004. Drip irrigation evaluated in Santa Maria Valley strawberries. Calif Agr 58(1):48-53

LeStrange M, Cahn MD, Kioke ST, et al. 2011. Broccoli Production in California. UC ANR Pub 7211. Oakland, CA. http://anrcatalog.ucdavis.edu.

Platts BE, Grismer ME. 2014. Chloride levels increase after 13 years of recycled water use in the Salinas Valley. Calif Agr 68(3):68-74 (this issue)

Smith R, Cahn M, Daugovish O, et al. 2011. Leaf Lettuce Production in California. UC ANR Pub 7216. Oakland, CA. http://anrcatalog.ucdavis.edu.

Weber E, Grattan SR, Hanson BR, et al. 2014. Recycled water causes no salinity or toxicity issues in $\mathrm{Napa}$ vineyards. Calif Agr 68(3):59-67 (this issue). 